\title{
Model Hidraulika untuk Simulasi Kejadian Banjir di Sungai Dumai
}

\author{
Asda Usradinda ${ }^{1}$, Sigit Sutikno ${ }^{2}$, Manyuk Fauzi ${ }^{3}$ \\ 1,2,3) Jurusan Teknik Sipil, Fakultas Teknik, Universitas Riau \\ Kampus Bina Widya Jl.HR Soebrantas KM 12,5 Pekanbaru, Kode Pos 28293 \\ Email : asda1975dmi@gmail.com
}

\begin{abstract}
ABSTRAK
Sebagai daerah yang secara geografis terletak di pesisir pantai, kota Dumai memiliki resiko terhadap banjir. Keberadaan sungai Dumai yang membelah kota Dumai merupakan pembuangan utama drainase dari beberapa kecamatan, diantaranya kecamatan Dumai Selatan, Dumai Timur dan Dumai Barat serta Dumai Kota. Penyebab banjir dikarenakan jumlah curah hujan dan kondisi tinggi muka pasang surut air laut, menyebabkan jumlah debit air yang melalui sungai, melebihi kapasitas daya tampung saluran pembuangan dan sungai. Berkaitan dengan hal tersebut, di dalam menganalisis dan memodelkan simulasi kemungkinan banjir yang terjadi di sungai Dumai, melalui penggunaan aplikasi permodelan hidraulika HECRAS. Dari hasil penelitian Daerah aliran sungai Dumai merupakan dataran rendah yang memiliki tinggi tebing/tanggul sungai yang bervariasi, baik disisi kiri maupun sisi kanan sungai. Hal ini berpengaruh terhadap kemampuan tebing/tanggul dalam menahan tinggi muka air banjir rencana atau naik turunnya air pasang laut. Dan mengakibatkan air yang melimpas tersebut mengalir kearah bantaran sungai yang memiliki kontur lebih rendah dan berpotensi menggenangi lahan dan pemukiman warga.
\end{abstract}

Kata Kunci : Sungai, Banjir, Model Hidraulika, Dumai

\begin{abstract}
As an area geographically located on the coast, Dumai city has a risk of flooding. The existence of the Dumai river, which divides the city of Dumai, is the primary drainage from several sub-districts, including the sub-districts of South Dumai, East Dumai and West Dumai and Dumai City. The cause of flooding due to the amount of rainfall and the high tide face condition of the seawater causes the amount of water discharged through the river to exceed the capacity of the drainage and river channels. In this regard, in analyzing and modeling simulations of possible flooding that occur in the Dumai river, through the use of the HEC-RAS hydraulic modeling application. From the results of the research, the Dumai watershed is a lowland area that has different riverbanks, both on the left and the right side of the river. The effect of the ability of cliffs/embankments to withstand planned flood water levels or sea tides. And resulting in runoff water flowing towards the river banks that have lower contours and potentially inundate land and residential areas.
\end{abstract}

Keywords: River, Flood, hydraulic model, Dumai. 


\section{Pendahuluan}

Kota Dumai adalah sebuah kota di Propinsi Riau, Indonesia, berjarak sekitar $188 \mathrm{~km}$ dari kota Pekanbaru. Dengan kondisi topografi datar dengan rata-rata ketinggian adalah 3 meter di atas muka laut, posisi kota Dumai mengarah ke utara berhadapan dengan pulau Rupat. Wilayah kota Dumai beriklim tropis dengan curah hujan di antara $100-300 \mathrm{~cm}$ dengan suhu udara $24-30{ }^{\circ} \mathrm{C}$. Sebagai daerah yang secara geografis terletak di pesisir pantai, kota Dumai memiliki resiko terhadap banjir yang disebabkan beberapa hal yang saling berhubungan antara satu sama lain. Adapun penyebab banjir yang pada umumnya terjadi dikarenakan jumlah curah hujan dan kondisi tinggi muka pasang surut air laut, menyebabkan jumlah debit air yang melalui sungai, melebihi kapasitas daya tampung saluran pembuangan dan sungai. Kondisi sungai dan rawa juga memiliki kaitan yang erat dalam terjadinya banjir. Penyebab lainnya adalah perubahan tata guna lahan dan tanah disepanjang Daerah Aliran Sungai yang sebagian besar kondisi aslinya merupakan tanah rawa.

Keberadaan sungai Dumai yang membelah kota Dumai merupakan pembuangan utama drainase dari beberapa kecamatan, diantaranya kecamatan Dumai Selatan, Dumai Timur dan Dumai Barat serta Dumai Kota, yang meliputi kelurahan Bumi Ayu, Sukajadi, Bukit Datuk, Ratu Sima, Rimba Sekampung, Bintan dan Laksamana. Daerah sekitar sungai Dumai ini umumnya merupakan daerah rawa yang masih banyak terdapat vegetasi dan dapat berfungsi menyimpan air. Proses hidrologi di suatu sungai sangat dipengaruhi oleh penggunaan lahan pada daerah di sekitar sungai tersebut. Beralih fungsinya kawasan vegetasi alami menjadi daerah pemukiman dan ruko di sekitar sungai Dumai menyebabkan peningkatan daerah kedap air, berakibat berkurangnya proses infiltrasi dan menambah besar nilai run off pada daerah aliran sungai (DAS) sungai Dumai. Peningkatan nilai run off tersebut, menambah besaran nilai debit air di sungai Dumai. Jika nilai debit air tersebut tidak dapat ditampung oleh sungai Dumai, maka permukaan air sungai akan naik menyebabkan terjadinya banjir dan dapat menimbulkan kerugian yang besar. Oleh sebab itu dibutuhkan penelitian/ kajian terkait dengan memodelkan hidraulika di sungai Dumai dengan maksud akan membantu memberikan solusi dalam mitigasi bencana banjir yang mungkin terjadi.

Berkaitan dengan hal tersebut, di dalam menganalisis dan memodelkan simulasi kemungkinan banjir yang terjadi di sungai Dumai, melalui penggunaan aplikasi permodelan hidraulika. Permodelan hidraulika akan membantu menyajikan informasi berupa sebaran dan tinggi muka air banjir. Dan salah satu model yang mengintegrasikan antara model hidraulik dengan Sistem Informasi Geografis adalah HEC-RAS. HEC-RAS adalah suatu aplikasi program yang digunakan dalam menganalisa dan memodelkan potensi banjir satu dimensi aliran permanen maupun tidak permanen. Dengan memodelkan genangan banjir berdasarkan penggabungan informasi geografis dan model hidraulika sehingga dapat menginterpolasikan tinggi muka air dan nilai debit pada suatu model hidraulika yang terdapat pada peta genangan banjir. 


\section{Metode Penelitian}

\section{Umum}

Proses tahapan kajian ini dalam tiga tahapan yaitu pengumpulan data, pengolahan data atau perhitungan yang akan menghasilkan keluaran berupa hasil analisis permodelan serta pembahasannya. Langkah-langkah yang diambil dalam prosedur penelitian ini adalah studi pustaka, pengumpulan dan pengolahan data sehingga didapatkan kesimpulan dan saran.

\section{Lokasi penelitian}

Penelitian ini dilakukan pada Daerah Aliran Sungai (DAS) Dumai pada kawasan kota Dumai.

\section{Prosedur penelitian}

Prosedur penelitian ini secara garis besar meliputi studi literatur, pengumpulan data, analisis hidrologi, pemodelan hidrolika dan analisis hasil pemodelan.

Metode dalam pengolahan data, perhitungan dan analisa yang digunakan dalam penelitian ini antara lain :

1. Kelengkapan data

Pemeriksaan terhadap kelengkapan data tinggi curah hujan maksimum dari periode pencatatan curah hujan yang memadai.

2. Pemeriksaan data

Pemeriksaan kualitas data hujan maupun debit hujan serta keandalannya, baik secara manual maupun statistik.

3. Analisis frekuensi

Analisis frekuensi bertujuan untuk menentukan jenis distribusi yang sesuai untuk mendapatkan curah hujan rencana. Jenis distribusi dipilih berdasarkan parameter statistiknya.

4. Uji kecocokan distribusi frekuensi

Pemeriksaan kecocokan jenis distribusi bertujuan untuk mengetahui apakah jenis distribusi yang telah dipilih dapat digunakan dengan uji Chi-kuadrat dan uji Smirnov-Kolmogorov.

5. Analisis intensitas hujan

Analisis curah hujan yang dilakukan adalah analisis penentuan intensitas hujan yang menunjukkan hubungan antara lamanya waktu hujan (durasi) dengan intensitas hujan, untuk masing-masing perioda ulang hujan.

6. Analisa laju aliran puncak (Q)

Pada penelitian ini perhitungan debit menggunakan metode rasional praktis.

7. Analisa hidraulika

Analisa hidraulika dengan melakukan pemodelan menggunakan HEC-RAS 4.1 guna mendapatkan tinggi genangan banjir dengan debit banjir rencana dari 
periode kala ulang tertentu.

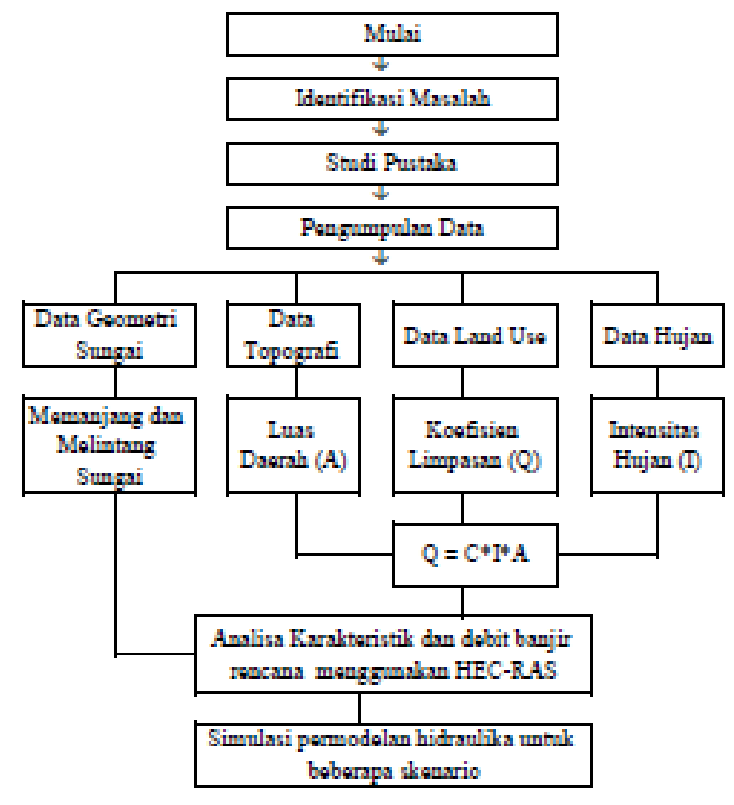

Gambar 1. Bagan alir penelitian

\section{Hasil dan Pembahasan}

\section{Hasil analisis hidrologi}

Data-data yang dikumpulkan dalam analisa hidrologi diperoleh dari instansi terkait (Stasiun Dumai) meliputi data yang digunakan berupa data curah hujan harian selama 38 tahun (tahun 1980-2017).

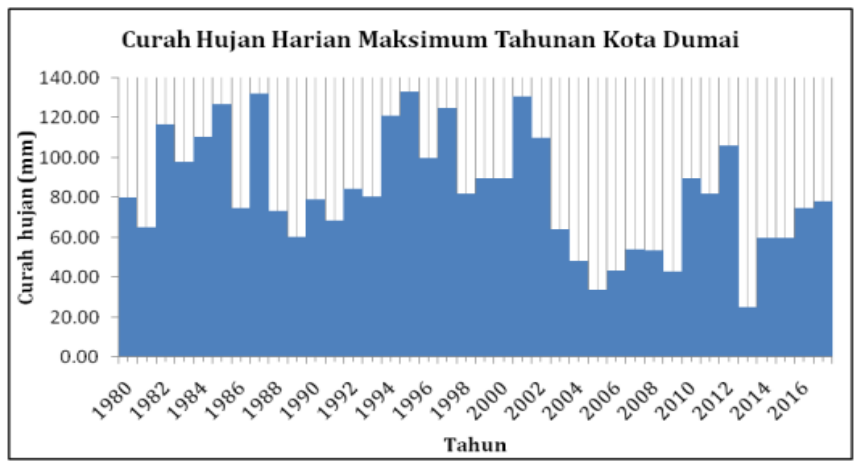

Gambar 2. Curah hujan harian maksimum tahunan stasiun Dumai

\section{Pemeriksaan dengan Kurva Massa Ganda}

Pada Gambar 3 menunjukkan garis yang terbentuk merupakan garis lurus dengan landai (slope) yang tidak berubah maka data yang diuji tersebut konsisten (panggah). 


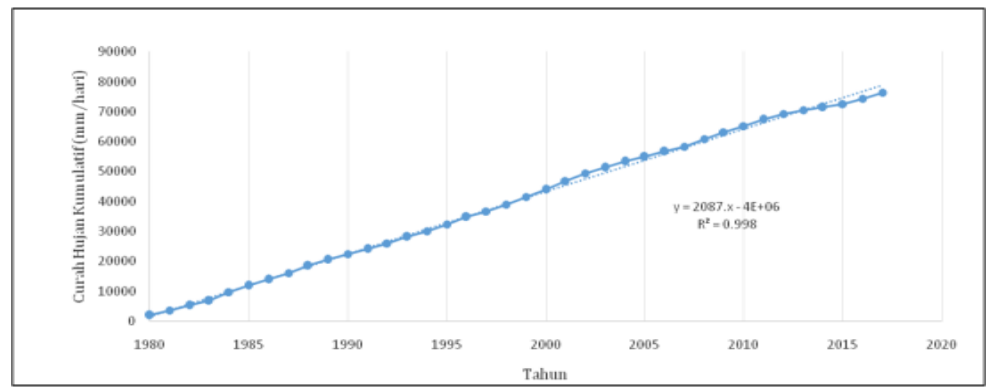

Gambar 3. Homogenitas data curah hujan Stasiun Dumai

\section{Pemeriksaan dengan RAPS}

Tabel 1. Besaran-besaran RAPS pada stasiun Dumai

\begin{tabular}{cccc}
\hline \multicolumn{5}{c}{ Kontrol 99\% } \\
\hline$Q / n^{0.5}$ & $0,069<1,654$ & Panggah \\
$R / n^{0.5}$ & $0,165<1,996$ & Panggah \\
\hline \multicolumn{5}{c}{ Kontrol 95\% } \\
\hline$Q / n^{0.5}$ & $0,069<1,364$ & Panggah \\
$R / n^{0.5}$ & $0,165<1,700$ & Panggah \\
\hline \multicolumn{5}{c}{ Kontrol 90\% } \\
\hline$Q / n^{0.5}$ & $0,069<1,190$ & Panggah \\
$R / n^{0.5}$ & $0,165<1,574$ & Panggah \\
\hline
\end{tabular}

Dari Tabel 1 dapat dilihat bahwa nilai $Q / \sqrt{ } \mathrm{n}$ hitungan untuk stasiun curah hujan yang diuji nilainya selalu lebih kecil dari $Q / \sqrt{ } \mathrm{n}$ tabel, sehingga dapat disimpulkan data curah hujan pada stasiun Dumai adalah data panggah atau konsisten.

\section{Analisis Curah Hujan rencana}

\section{Analisis distribusi frekuensi}

Didapatkan hasil perhitungan dengan nilai sebagai berikut:
a. Nilai rata-rata $(\mathrm{x})=82,8816 \mathrm{~mm}$
b. Standar Deviasi $(\mathrm{Sd})=28,8748$
c. Nilai Skewness $(\mathrm{Cs})=0,0866$
d. Nilai Kurtosis $(\mathrm{Ck})=2,48$
e. Koefisien Variansi $(\mathrm{Cv})=0,3484$

Dari hasil perhitungan, dapat disimpulkan bahwa distribusi yang dapat digunakan adalah distribusi Log Pearson III dan didapatkan hasil sebagai berikut. 
Tabel 3. Curah hujan rencana

\begin{tabular}{|c|c|c|c|c|}
\hline Kala Ulang & $\mathbf{P ~ ( \% )}$ & $\mathbf{K T}$ & $\log \mathbf{X}$ & $\mathbf{X}$ \\
\hline 2 & 50 & 0,002 & 1,89 & 77,50 \\
\hline 5 & 25 & 0,846 & 2,03 & 107,88 \\
\hline 10 & 20 & 1,270 & 2,11 & 127,37 \\
\hline 20 & 10 & 1,640 & 2,17 & 147,24 \\
\hline 25 & 4 & 1,716 & 2,18 & 151,69 \\
\hline 50 & 2 & 2,000 & 2,23 & 169,54 \\
\hline
\end{tabular}

\section{Analisa Debit Rencana Metoda Rasional Praktis}

Dengan menggunakan data foto udara kota Dumai, dapat dipetakan penggunaan lahan di DAS sungai Dumai seperti pada gambar dibawah ini.



Gambar 4. Peta penggunaan lahan

Dengan menggunakan Metoda Rasional Praktis didapatkan hasil perhitungan sebagai berikut.

$$
\begin{array}{lll}
- & \text { Luas Area DAS (A) } & =103,8264 \mathrm{~km} 2 \\
- & \text { Panjang Sungai (L) } & =4,473+5,592=10,065 \mathrm{~km}
\end{array}
$$

Hasil perhitungan intensitas hujan pada periode ulang disajikan pada Tabel 5 berikut. 
Tabel 5. Intensitas hujan pada periode ulang

\begin{tabular}{|c|c|c|c|c|c|c|}
\hline Intensitas hujan & I 2 & I 5 & I 10 & I 20 & I 25 & I 50 \\
\hline Hasil (mm/jam) & 6,91 & 9,63 & 11,36 & 13,14 & 13,53 & 15,13 \\
\hline
\end{tabular}

Perhitungan tc yaitu :

$$
t c=\left[\frac{0,87 \times 10,065^{2}}{1000 \times 0,0004451}\right]^{0,385}=7,66 \mathrm{jam}
$$

Pada Tabel 6 disajikan nilai koefisien aliran (C) komposit untuk DAS sungai Dumai.

Tabel 6. Nilai koefisien aliran C komposit

\begin{tabular}{|c|l|c|c|c|}
\hline \multirow{2}{*}{ No } & \multirow{2}{*}{ Pengunaan Lahan } & $\begin{array}{c}\text { Luasan } \\
\mathbf{( k m 2 )}\end{array}$ & $\begin{array}{c}\text { Koefisin } \\
\text { Aliran }\end{array}$ & \multirow{2}{*}{ A x C } \\
\cline { 3 - 4 } & & $\mathbf{A}$ & $\mathbf{C}$ & \\
\hline 1 & Perkerasan Jalan & 0,25 & 0,70 & 0,18 \\
\hline 2 & Pabrik dan Industri & 4,95 & 0,70 & 3,47 \\
\hline 3 & Perkampungan & 8,62 & 0,24 & 2,07 \\
\hline 4 & Perkotaan & 21,66 & 0,70 & 15,16 \\
\hline 5 & Vegetasi dan Hutan & 68,35 & 0,25 & 17,09 \\
\hline & & $\mathbf{1 0 3 , 8 3}$ & & $\mathbf{3 7 , 9 6}$ \\
\hline
\end{tabular}

Untuk mendapatkan nilai C 100\% yaitu:

$$
C 100 \%=\frac{37,96}{103,83}=0,34
$$

Dengan menggunakan metode Rasional praktis, dapat dihitung debit banjir dengan:

$$
Q 2=0,278 \times 6,915 \times 103,83 \times 0,34=72,97 \mathrm{~m} 3 / \text { detik }
$$

\begin{tabular}{|c|c|c|c|c|c|c|}
\hline $\begin{array}{l}\text { Periode } \\
\text { (tahun) }\end{array}$ & $\begin{array}{l}R \max \\
(\mathrm{mm})\end{array}$ & $\begin{array}{c}\text { tc } \\
\text { (jam) }\end{array}$ & $\begin{array}{c}\mathrm{I} \\
(\mathrm{mm} / \mathrm{jam})\end{array}$ & C & $\begin{array}{c}\text { A } \\
(\mathrm{km} 2)\end{array}$ & $\begin{array}{c}\text { Q } \\
\text { (m3/dtk) }\end{array}$ \\
\hline 2 & 77,50 & \multirow{6}{*}{7,66} & 6,915 & \multirow{6}{*}{0,37} & \multirow{6}{*}{103,83} & 72,97 \\
\hline 5 & 107,88 & & 9,625 & & & 101,57 \\
\hline 10 & 127,37 & & 11,364 & & & 119,92 \\
\hline 20 & 147,24 & & 13,137 & & & 138,62 \\
\hline 25 & 151,69 & & 13,534 & & & 142,81 \\
\hline 50 & 169,54 & & 15,126 & & & 159,62 \\
\hline
\end{tabular}

Hasil perhitungan debit banjir rencana selengkapnya dapat dilihat pada Tabel 7.

Tabel 7. Debit banjir pada periode ulang 


\section{Hasil analisis Hidrolika sungai Dumai}

\section{Peniruan geometri sungai Dumai}

Data geometri penampang sungai/saluran yang ada diambil dari hasil survei lapangan dan peta topografi yang ada. Jarak cross section diukur dari hilir sungai menuju hulu sungai dengan jarak antara 25 sampai dengan 100 meter. Jarak antara cross section yang pendek dibutuhkan pada daerah tikungan.

Peniruan geometri sungai Dumai dapat dilihat pada Gambar 5.



Gambar 5. Pemodelan sistem sungai Dumai

Data debit yang digunakan dalam permodelan:

Tabel 8. Debit banjir rencana

\begin{tabular}{|c|c|c|c|c|c|c|}
\hline Periode (tahun) & 2 & 5 & 10 & 20 & 25 & 50 \\
\hline $\mathrm{Q}$ (m3/detik) & 72,97 & 101,57 & 119,92 & 138,62 & 142,81 & 159,62 \\
\hline
\end{tabular}

Hasil simulasi output program

Dapat digambarkan kondisi penampang memanjang hasil permodelan (2 dimensi) kala ulang banjir 2, 25 dan 50 tahun seperti pada Gambar 9. 


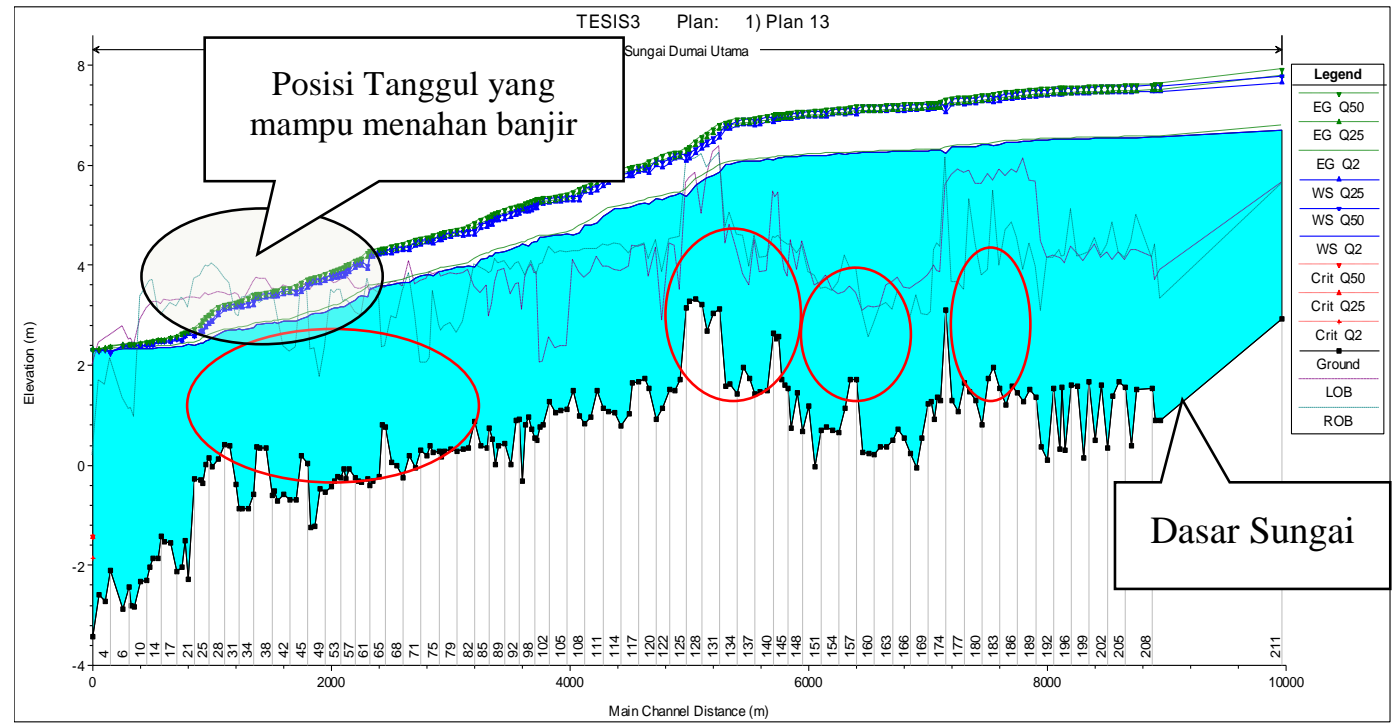

Gambar 9. Hasil pemodelan di sungai Dumai (2 dimensi)

Hasil permodelan analisa hidrolika dipetakan genangan yang terjadi pada Gambar 10.

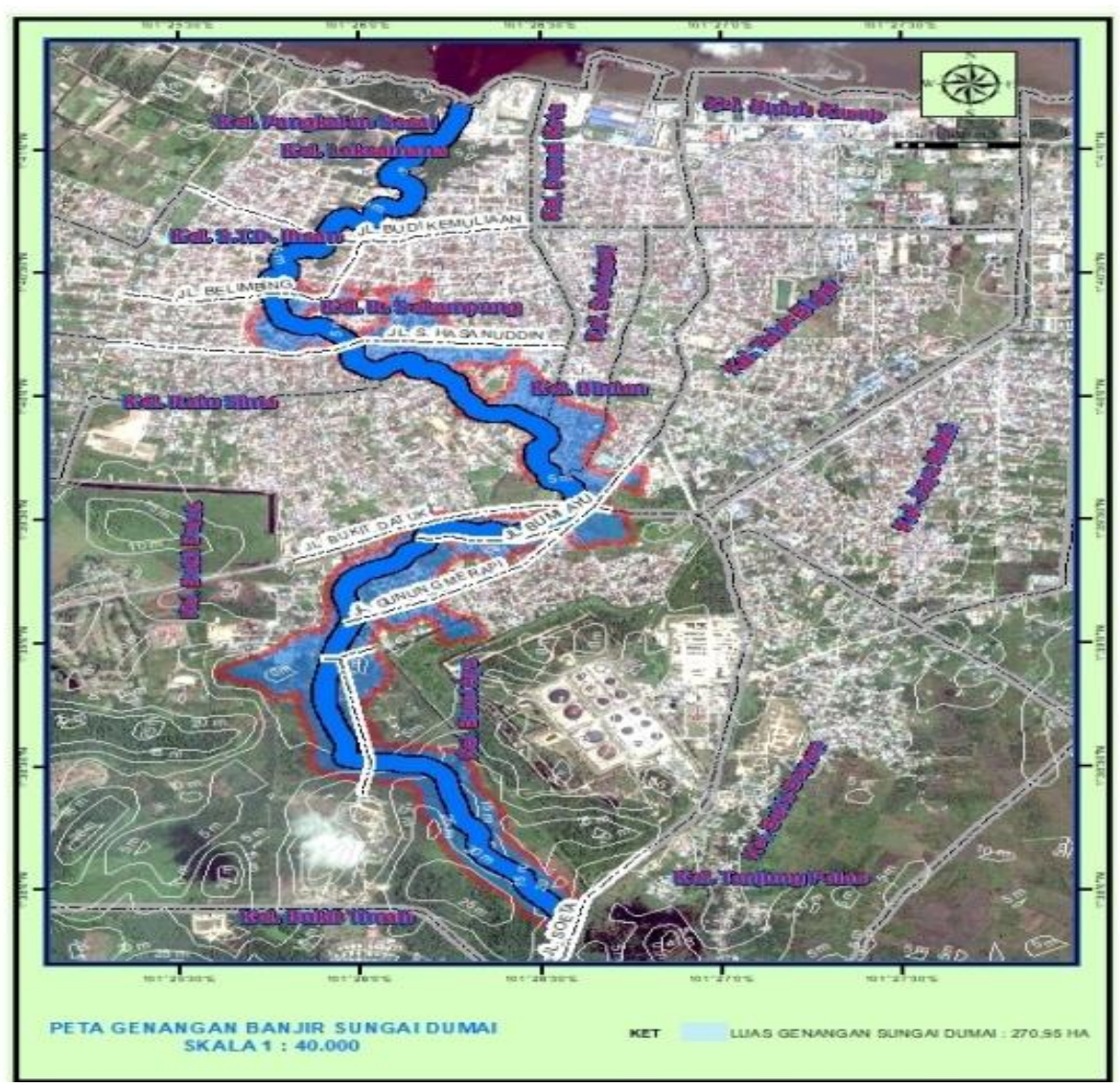

Gambar 10. Peta genangan yang terjadi

UNITEX Vol 12 No.2 Juli-Desember 2019 p-ISSN 2089-3957 | e-ISSN 2580-2585 


\section{Simpulan}

Dari hasil penelitian yang telah dilakukan, maka dapat disimpulkan hal-hal sebagai berikut yaitu daerah aliran sungai Dumai merupakan dataran rendah yang memiliki tinggi tebing/tanggul bervariasi, baik sisi kiri maupun kanan sungai. Hal ini berpengaruh terhadap kemampuan tebing/tanggul dalam menahan tinggi muka air banjir rencana atau naik turunnya air pasang laut. Tentunya air yang melimpas tersebut mengalir kearah bantaran sungai yang memiliki kontur lebih rendah dan berpotensi menggenangi lahan dan pemukiman warga.

Ada beberapa bagian pada sungai Dumai yang memiliki dasar saluran lebih tinggi dari posisi sebelum dan sesudahnya. Dapat dirangkum kondisi ini terjadi pada Sta 0+851 s/d 1+151 dan Sta 4+969 s/d 5+257 serta beberapa segmen lainnya. Hal ini terjadi akibat pendangkalan dasar saluran dan berpengaruh terhadap laju aliran air. Hasil permodelan kala ulang 2 tahun, 25 tahun dan 50 tahun menunjukkan trend yang sama pada bagian hilir sungai. Ketinggian muka banjir memiliki nilai yang sama sebesar 0,3 meter diatas tebing sisi kiri dan 1,01 meter untuk tebing sisi kanan dikarenakan tinngi pasang air laut diketahui 2,30 meter.

Hasil permodelan pada bagian tengah sungai (Sta 5+300) mengalami kenaikan muka banjir yang bervariasi. Pada kala ulang 2 tahun, ketinggian muka banjir sebesar 1,58 meter di atas tanggul kiri dan 1,26 meter diatas tanggul kanan. Pada kala ulang 25 tahun, ketinggian muka banjir sebesar 2,29 meter diatas tanggul kiri dan 1,97 meter diatas tanggul kanan. Pada kala ulang 50 tahun, ketinggian muka banjir sebesar 2,38 meter diatas tanggul kiri dan diatas tanggul kanan 2,06 meter.

Hasil permodelan pada bagian hulu sungai (Sta 10+065) mengalami kenaikan muka banjir yang bervariasi. Pada kala ulang 2 tahun, ketinggian muka banjir sebesar 0,80 meter di atas tanggul kiri dan 0,94 meter diatas tanggul kanan. Pada kala ulang 25 tahun, ketinggian muka banjir sebesar 1,43 meter diatas tanggul kiri dan 1,57 meter diatas tanggul kanan. Pada kala ulang 50 tahun, ketinggian muka banjir sebesar 1,51 meter diatas tanggul kiri dan diatas tanggul kanan 1,65 meter.

\section{Daftar Pustaka}

Anonim. (2016). SNI 03-2415-1991 Rev. 2016: Tata Cara Perhitungan Debit Banjir, Badan Standarisasi Nasional.

Asdak, Chay. (1995). Hidrologi dan Pengelolaan Daerah Aliran Sungai. Gajah Mada University Press. Yogyakarta.

Chow, VT. (1970). Hidrolika Saluran Terbuka Open (Open Channel Hydraulics). PT. Gelora Aksara Pratama. 
Asril. (2014). Analisis potensi resiko banjir pada DAS yang mencakup kota Medan dengan menggunakan Sistem Informasi Geografis (SIG). Tesis tidak diterbitkan, Fakultas Teknik, Universitas Sumatera Utara, Medan.

Azizah. (2015). Studi perencanaan tanggul dan dinding penahan untuk pengendalian banjir di sungai Cileungsi Kabupaten Bogor Jawa Barat. Skripsi tidak diterbitkan, Fakultas Teknik, Universitas Brawijaya, Malang.

Aryanto, A. (2010). Pengaruh Perubahan Penutup Lahan Terhadap Debit Aliran Permukaan di Sub DAS Keduang Wonogiri. Skripsi tidak diterbitkan, Fakultas Teknik, Universitas Sebelas Maret, Surakarta.

Harto, Sri Br. (1993). Analisis Hidrologi. Jakarta: Gramedia Pustaka Utama.

Indarto. (2010). Hidrologi Dasar Teori Dan Contoh Aplikasi Model Hidrologi. Jakarta. PT. Bumi Aksara.

Irwan, Sukri Banuwa. (2013). Erosi. Jakarta: Kencana.

Istiarto. (2014). Simulasi Aliran 1-Dimensi Dengan Bantuan Paket Program HidrodnamikaHEC-RAS. http://istiarto.staff.ugm.ac.id/istiarto@ugm.ac.id

Kamiana, I Made. (2011). Teknik Perhitungan Data Rencana Bangunan Air. Yogyakarta. Graha Ilmu.

Karya Dinamis, CV. (2011). Laporan Final Perencanaan Rencana Induk Sistem (RIS) Perkotaan Dumai, Dinas Pekerjaan Umum, Dumai.

Kodoatie, J Robert, (2013). Rekayasa dan Manajemen Banjir Kota, Yogyakarta Penerbit Andi.

Mitra Utama Estuari, PT. (2017). Laporan Akhir DED Pengaman Tebing dan Pengendalian Banjir Sungai Dumai, Dinas Pekerjaan Umum dan Penataan Ruang, Dumai.

Sandy. (1985). Morfologi Daerah Aliran Sungai. Guru Besar Jurusan Geografi Universitas Indonesia, Jakarta.

Sinukaban, N. (2007). Peranan Konservasi Tanah dan Air dalam Pengelolaan Daerah Aliran Sungai. Ketua Umum Pengurus Pusat MKTI Periode 2004-2007 Jurusan Ilmu Tanha, Institut Pertanian Bogor.

Soemarto, CD. (1997). Hidrologi Teknik. Surabaya. Usaha Nasional.

Suripin. (2004). Sistem Drainase Perkotaan yang Berkelanjutan. Yogyakarta: Andi.

Suripin. (2004). Pelestarian Sumber Daya Tanah dan Air. Yogyakarta: Andi. 
Triatmodjo, Bambang. (1993). Hidrologi I. Yogyakarta: Beta Offset.

Triatmodjo, Bambang. (2009). Hidrologi Terapan. Yogyakarta: Beta Offset.

Triatmodjo, Bambang. (2011). Perencanaan Bangunan Pantai. Yogyakarta: Beta Offset.

U.S Army Corps of Engineers - Hydrologic Engineering Center (HEC). (2010). Hydraulic Reference Manual HEC-RAS 4.10. California: U.S. Army Corps of Engineers. 